\title{
Cognitive Bias in a Disruptive Era: How Thinking Patterns Affects Academic Performance and Health
}

\author{
Ali Maksum and Fifuka D. Khory \\ Sports Science Faculty \\ Universitas Negeri Surabaya \\ Surabaya, Indonesia \\ alimaksum@unesa.ac.id
}

\begin{abstract}
In a disruptive era marked by rapid changes and an abundance of information, the occurrence of cognitive biases becomes difficult to avoid. Individuals are more confident in something perceived than the facts and actual data. Emotions are stronger than reason. In a neuropsychological perspective, people tend to use the limbic system rather than the neocortex in thinking and responding to things. As a result, opportunities for mistakes in making decisions more often occur. In the long run, such conditions will distort the academic climate that promotes rationality and critical thinking. The results of a study of 1000 students of Universitas Negeri Surabaya (Unesa) in seven faculties and postgraduate programs showed that cognitive bias occurred in $81 \%$ of respondents. Deprivation is deeper in social science students than exact science students. Other relevant research also shows that students who use intuitive thinking patterns have lower academic performance compared to students who use reflective thinking patterns. Intuitive thinking patterns also encourage students to cheat, and their eating patterns are very risky for health.
\end{abstract}

Keywords: academic performance, cognitive bias, health, thinking patterns

\section{INTRODUCTION}

In the field of psychology, a cognitive bias is not new. Studies on this matter have been around since 1979 when Amos Tversky and Daniel Kahneman wrote an article about their research entitled "Prospect theory: An analysis of decision under risk". This issue became a public concern after Kahneman won the Nobel Prize in economics in 2002. According to references [1], as he described in his book: Thinking, fast and slow, said that humans generally experience bias in providing judgment and making decisions. Today, the problem of cognitive bias becomes urgent to be studied as the strengthening of populism culture and hegemony of social media which have a big influence on life. In a disruptive era characterized by rapid change and abundance of information, the occurrence of cognitive biases becomes something that is difficult to avoid. Cognitive bias is a fallacy in thinking that affects individuals in making judgments and inferences. Mistakes in thinking can result in mistakes in acting. Cognitive biases can occur due to the inability of individuals to process information, excessive emotions, personal interests, or pressure from outside themselves.

In such conditions, people no longer think clearly and critically about the truth. They tend to accept truth based on their emotions and beliefs rather than on facts. The truth seems not determined by data and facts, but by individual and group perceptions and beliefs. Reference [2] calls it the death of expertise. When there are facts that are in line with their beliefs, they are convinced of the truth of the facts without verifying. The abundance of information that is often called "big data" is apparently not linear with the individual's ability to act and make decisions. What emerges is precisely the epidemic of irrationality, which is characterized by the loss of rational thought and a lack of awareness of the importance of the verification process before concluding. People become rushed, spontaneous, instant, and always driven to be the fastest without thinking of the underlying truth.

If the individual is accustomed to using intuitive thinking models, then, in the long run, his mind will not function properly. Critical thinking habits become undeveloped. As a result, individuals lose the reference to understanding problems clearly, including solving problems in life. This situation is not only unfavourable but also counterproductive to progress. It must be admitted that our educational process cannot produce higher-order thinking skills. In competitions that test critical thinking skills and ability to overcome problems such as PISA (a program for international student assessment) and TIMSS (trends in international mathematics and science study), the reasoning power of Indonesian children is very low. In PISA, for example, of the 65 countries that were assessed, Indonesia ranked $64^{\text {th }}$. While Malaysia ranked $52^{\text {nd }}$, Thailand ranked $50^{\text {th }}$, Singapore ranked $2^{\text {nd }}$, and China ranked $1^{\text {st }}$ [3]. In the 2015 TIMSS, for mathematics, Indonesia was ranked 45 out of 50 countries surveyed. While in the field of science, Indonesia's ranking is in 45 out of 48 countries [4].

In many studies, thinking models are closely related to the curiosity of new information and experiences [5], including creative thinking and problem solving [6-7]. Thinking patterns are also related to academic processes and performance [8-11], namely how students respond to any information on existing learning resources. Learning is not just meant as an effort to get academic value as measured by the GPA, but rather as an effort to build a civilization that educates the nation's life as the spirit of Law No. 12 of 2012. Thinking also influences one's lifestyle and health [12-13]. Health problems suffered by a person can be traced from the mindset they have, including in responding to the food around them.

\section{A. Neuro-Psychological Perspective}

The study of thinking and acting on human beings has long been a concern of humanities scientists, especially psychology and sociology. But later, it became interesting because of the involvement of neuroscience in the discourse. Neuroscience has developed rapidly in the past twenty years 
Both systems exist in the human mind and interact with as scientists have a strong curiosity to unravel the mysteries of the human brain that is so complex, both in structure and in the way it works. In terms of neuropsychology, scientists have concluded that the brain is the centre of command and control of human behaviour. They also discovered the fact that the behaviour displayed by humans turned out to have a neuro basis in brain structure [12], [14-15]. Referring to the concept of a triune, the brain structure consists of three parts, namely the brain stem (reptilian brain), limbic system (mammalian brain), and neocortex (human brain). The brain stem area, including the cerebellum, is responsible for things that are instinctive survival, such as breathing, hunger, thirst, sex, and fight or flight response. The limbic system area, including the amygdala, hypothalamus, thalamus, basal ganglia, and lateral temporal cortex, is responsible for emotions such as pleasure, sadness, joy, jealousy, fear, and anger. As for the neocortex area, including the anterior cingulate cortex, prefrontal cortex, medial temporal, and hippocampus, it is responsible for matters related to intellectual, reasoning, thinking, control, morals, and consciousness. Thus, there is a close relationship between the brain and someone's behaviour. The relationship between the two is reciprocal, and the brain affects behaviour and vice versa behaviour can affect the physical form of the brain in accordance with the principle of neuroplasticity. Individuals who in their activities use a lot of brain stem and limbic system areas, then the neocortex area will be weakened. Physical changes and brain activity will be seen if laboratory analyzes such as MRI (magnetic resonance imaging) and EEG (electroencephalograms) are carried out, while behavioural changes can be observed through observation, tests and other forms of measurement. Differences in Characteristic and Mechanism between System 1 and System

\begin{tabular}{|l|l|}
\hline \multicolumn{1}{|c|}{ System 1 } & \multicolumn{1}{c|}{ System 2 } \\
\hline $\begin{array}{l}\text { Based on the limbic system } \\
\text { (amygdala, hypothalamus, basal } \\
\text { ganglia) }\end{array}$ & $\begin{array}{l}\text { Based on neocortex (anterior } \\
\text { cingulate cortex, prefrontal } \\
\text { cortex, hippocampus) }\end{array}$ \\
\hline Evolutionarily old & Evolutionarily recent \\
\hline Shared with animal & Uniquely human \\
\hline Default mechanism & Custom mechanism \\
\hline Intuitive & Analytic \\
\hline $\begin{array}{l}\text { Aggression } \\
\text { Unconscious }\end{array}$ & $\begin{array}{l}\text { Moral } \\
\text { Conscious }\end{array}$ \\
\hline Automatic & Controlled \\
\hline Perception & Fact, data \\
\hline Low effort, comfort zone & High effort, change \\
\hline Holistic & Analytic \\
\hline Pragmatic & Logical \\
\hline Stereotypical & Egalitarian \\
\hline
\end{tabular}

Based on dual-processing theory [1], [16], the thought process has two mechanisms, namely system 1 that operates on the limbic system and system 2 that operates on the neocortex (see table 1). System 1 is the default mechanism in the brain. Every incoming stimulus will be responded to first by the limbic system, which is the place of emotion. System 1 is characterized by a decision-making process that is emotional, intuitive, automatic, lacks in-depth consideration, and is difficult to control over instinctive desires. Meanwhile, system 2 is a custom mechanism in the brain. It only functions when activated and managed. System 2 is characterized by rational decision making, requires in-depth consideration, is relatively flexible, and is adaptive to rules. each other. There is a strong association between the neocortex and the limbic system, between reason and emotion. When reason strengthens, emotion will weaken, and when emotions strengthen, reason will weaken. The function of reason is inversely proportional to emotions. The neocortex area in the brain structure needs to be optimized and reasoning activated. At the same time, the limbic system needs to be managed and self-control strengthened. Attitudes and actions that predominantly exploit the limbic system will make the neocortex become atrophy, the reasoning is not functioning optimally, and in turn, will reduce the degree of humanity. This theory is likely to explain the mental phenomena and deviant behaviour of some people lately. Deviant behaviour often occurs because individuals have no other alternative due to limitations in mind. Students who cheat can be due to lack of answers in their minds, students/lecturers who are plagiarism can be due to lack of skills in writing ideas in writing, corrupt people can be due to lack of thoughts to gain wealth the right way, and even people who are disappointed or hurt then committing acts of violence, including killing, is very likely due to the lack of alternatives in his mind to solve problems constructively.

\section{Methodology}

Samples of our study consisted of 1000 Universitas Negeri Surabaya (Surabaya State University) students, consisting of 324 men and 676 women. Descriptive statistics were used in this study to understand the academic performance of students based on self-control ability. The analysis of data was used T-test to understand the differences among scores of math, the score of Indonesian and score of religion.

\section{RESULTS AND DISCUSSION}

\section{A. Thinking Patterns and Academic Performance}

The results of our study of 1000 Universitas Negeri Surabaya (Surabaya State University) students, consisting of 324 men and 676 women, showed that $81 \%$ of students used intuitive thinking patterns and $19 \%$ used reflective thinking [17]. These findings also confirm that the default mechanism in the brain is to think intuitively and will respond to stimuli based on emotions unless they are activating their reasoning. The low level of thinking and the low quality of education is also due to these factors. From a gender aspect, women are more dominant using intuitive thinking patterns than men. This finding also confirms the statement that women tend to use emotions rather than their thoughts.

Many students who use intuitive thinking patterns show that they are not able to control emotional impulses in themselves. Mechanically, the stimulus that enters the brain will be responded to first by the limbic system in which emotions reside. If the information process only stops at the limbic system, then there will be no analysis and evaluation of that information, considering that rational considerations only occur in the neocortex. As a result, the performance of the mind will not be maximized.

Testing the relationship model between variables by using structural equation modelling shows that thinking patterns affect curiosity, and curiosity wants to influence academic performance [17]. Of the five aspects of mindset, three aspects including the seriousness of effort, evaluation, 
them, $35 \%$ answered directly eaten, and $65 \%$ answered saved first. The students were further explored in relation to academic achievement at school as measured by mathematics, Indonesian, and religion. The results of the study prove that children who can control themselves show better learning achievement compared to children who cannot control themselves (see table 2). problems. Thinking skills and curiosity are important factors in building a creative and innovative culture that impacts the nation's competitiveness. Referring to the results of previous studies that there are two things that are still a problem of the quality of education until now, namely critical thinking and problem-solving. Critical thinking is the ability to analyze and evaluate something based on relevant logic, information and data. While problem-solving is the ability to find the right solution to a problem. Both are important parts of $21 \mathrm{st}-$ century skills. A country that dreams of competitiveness needs to pay serious attention to both.

TABLE I. ACADEMIC PERFormance OF STUdENTS BASED ON SElFCONTROL ABILITY

\begin{tabular}{|c|c|c|c|c|c|}
\hline & Self-control & N & Mean & SD & SEM \\
\hline \multirow{2}{*}{ Score of Math } & Low & 250 & 79.78 & 8.593 & .543 \\
\cline { 2 - 6 } & High & 455 & 82.11 & 7.210 & .338 \\
\hline \multirow{2}{*}{ Score of Indonesian } & Low & 250 & 81.96 & 6.117 & .387 \\
\cline { 2 - 6 } & High & 455 & 84.42 & 5.939 & .278 \\
\hline \multirow{2}{*}{ Score of Religion } & Low & 250 & 83.32 & 7.827 & .495 \\
\cline { 2 - 6 } & High & 455 & 84.97 & 5.946 & .279 \\
\hline
\end{tabular}

TABLE II. ACADEMIC PERFORMANCE OF STUDENTS BASED ON SELFCONTROL ABILITY

\begin{tabular}{|c|c|c|c|c|c|c|c|c|}
\hline & \multicolumn{2}{|c|}{$\begin{array}{c}\text { Levene's Test } \\
\text { for Equality of } \\
\text { Variances }\end{array}$} & \multicolumn{5}{|c|}{ T-test for equality of means } \\
\hline & & $\mathrm{F}$ & Sig. & $\mathrm{T}$ & Df & $\begin{array}{l}\text { Sig. } \\
(2- \\
\text { tailed }) \\
\end{array}$ & $\begin{array}{c}\text { Mean } \\
\text { Differe } \\
\text { nce }\end{array}$ & \begin{tabular}{|c|} 
Std. \\
Error \\
Differen \\
ce \\
\end{tabular} \\
\hline \multirow[t]{2}{*}{$\begin{array}{l}\text { Score } \\
\text { of } \\
\text { Math }\end{array}$} & $\begin{array}{l}\text { Equal } \\
\text { variances } \\
\text { assumed }\end{array}$ & .332 & .565 & -3.837 & 703 & .000 & -2.334 & .608 \\
\hline & \begin{tabular}{|l} 
Equal \\
variances \\
not \\
assumed \\
\end{tabular} & & & -3.647 & $\begin{array}{l}442.5 \\
61\end{array}$ & .000 & -2.334 & .640 \\
\hline \multirow{2}{*}{\begin{tabular}{|l|} 
Score \\
of \\
Indo- \\
nesian
\end{tabular}} & $\begin{array}{l}\text { Equal } \\
\text { variances } \\
\text { assumed }\end{array}$ & .287 & .592 & -5.197 & 703 & .000 & -2.456 & .473 \\
\hline & \begin{tabular}{|l} 
Equal \\
variances \\
not \\
assumed
\end{tabular} & & & -5.152 & $\begin{array}{l}500.1 \\
71\end{array}$ & .000 & -2.456 & .477 \\
\hline \multirow{2}{*}{$\begin{array}{l}\text { Score } \\
\text { of } \\
\text { Reli- } \\
\text { gion }\end{array}$} & $\begin{array}{l}\text { Equal } \\
\text { variances } \\
\text { assumed }\end{array}$ & 7.031 & .008 & -3.135 & 703 & .002 & -1.647 & .525 \\
\hline & \begin{tabular}{|l|} 
Equal \\
variances \\
not \\
assumed
\end{tabular} & & & -2.899 & $\begin{array}{l}409.3 \\
85\end{array}$ & .004 & -1.647 & .568 \\
\hline
\end{tabular}

In addition to optimizing the function of reason, the next task is to control emotions that reside in the limbic system. Related to this problem, I would like to explain the results of research conducted on 705 elementary and junior high school students in Surabaya. The research modified the classic experiment conducted by Walter Mischel on a group of children given Marshmello [18]. The elementary and middle school students were asked, if you are given delicious chocolate, do you immediately eat it or save it first? Among

\section{B. Thinking Patterns, Lifestyle, and Health}

Thinking patterns affect not only academic performance but also lifestyle including health. Individuals who can use their minds well will avoid things that can interfere with their health. In the case of eating, for example, an individual who activates neocortex will consider the type of food he consumes. As a massive culinary promotion followed by the ease of getting it through a smartphone application makes it difficult for people not to be tempted. Our survey of 705 students in Surabaya showed that $87.9 \%$ of students had smartphones, of which $76.2 \%$ liked using video games. A large number of smartphone users is certainly a potential students who liked to eat fried foods amounted to $64.7 \%$, liked food /sweet drinks by $88.6 \%$, and liked to eat / drink in packages by $73.9 \%$. The results of statistical analysis prove that students who like to eat out and don't like to eat vegetables are more likely to face health problems than students who don't like to eat out and like to eat vegetables.

Lifestyle problems must be a serious concern because of their impact on the quality of human resources going forward. Reference [19] through its report in 2018 stated that non-communicable diseases would continue to be of global concern through the SDGs program as global commitments are weak, both in the form of legislation, budgeting, and implementation? In 2014, WHO conducted a global survey and lowered the profile report of each country related to noncommunicable diseases. In the case of Indonesia, WHO noted that non-infectious diseases - such as heart disease, stroke, acute breathing, and diabetes mellitus - caused death by $71 \%$. It seems that there has been a significant increase from year to year. In 1995, the death rate due to noncommunicable diseases was $41.7 \%$, in 2001 it was $49.9 \%$, and in 2007 it was $59.5 \%$. The results of the one-year evaluation of the implementation of the national health insurance (BPJS) show that the number of sick Indonesian population reaches $65 \%$, far exceeding the normal standard of $10-15 \%$ of the total population [20]. Participant fees received by the BPJS Health cannot cover the budget that must be spent to pay for the sick, so they tend to continue to lose money. Data for 2017 shows that health BPJS has a deficit of 9 trillion [21]. and at the end of 2019, it is estimated to have a deficit of 28 trillion [22]. The biggest portion of the budget is spent to pay for non-infectious diseases, such as heart, kidney, diabetes, and stroke. This disease is generally caused by unhealthy lifestyles, including due to lack of movement.

The conditions as described above, basically correlate with the level of fitness of students. National data shows that over time, student fitness levels continue to decline [23]. In 1995, the fitness level of students which was categorized as good was $16.9 \%$, in 2005 it became $5.6 \%$, and in 2011 it fell again to $4 \%$. While physical fitness was categorized as very poor, in 1995 it was $5.9 \%$, in 2005 it became $10.71 \%$, and in 2011 it rose significantly to 60\%. Such conditions are certainly very alarming. target market. The results of the study also mentioned that 
students in Indonesia". Hayati Journal of Biosciences, vol. 23, p. 121124, Elsevier B.V. 2016.

Thinking patterns become crucial as change continues. We cannot control the changes that are and will continue to occur, which directly or indirectly, will affect our lives. What can be done is to manage the mind to respond accordingly. Intuitive thinking which is the default mechanism in the brain has dominated most individuals and influenced life, including academic performance and health. Therefore, emotions that reside in the limbic system must be controlled. Furthermore, we continue to promote reflective thinking, activating reasoning in the neocortex, which seeks to analyze and evaluate each stimulus, in order to obtain optimal academic and health performance.

\section{REFERENCES}

[1] D. Kahneman, Thinking fast and slow. New York: Penguin Group, 2011

[2] T. Nichols, The death of expertise: The Campaign against established knowledge and why it matters. New York: Oxford University Press. 2017.

[3] OECD, PISA 2012 Results in Focus: What 15-year-olds know and what they can do with what they know, 2013.

[4] TIMSS and PIRLS, TIMSS 2015 international results. Boston: International Study Center, 2015

[5] R. Ligneul, M. Mermillod, and T. Morisseau, "From relief to surprise: Dual control of epistemic curiosity in the human brain" NeuroImage, Volume 181, pp 490-500, 2018.

[6] L. P. Hagtvedt, K. Dossinger, S. H. Harrison, and L. Huang, Curiosity made the cat more creative: Specific curiosity as a driver of creativity. Organizational Behavior and Human Decision Processes, Volume 150, Pages 1-13, 2019

[7] J. H. Hardy, A. M. Ness, J. Mecca, Outside the box: Epistemic curiosity as a predictor of creative problem solving and creative performance. Personality and Individual Differences, Volume 104, Pages 230-237, 2017

[8] N. Wulandari, K. A. Widayati, and B. Suryobroto, "Cognitive style and creativity quality: Influence on achievement of university
[9] I. V. Grebenev, L. B. Lozovskaya, and E. O. Morozova, "Methodology of determining student's cognitive styles and its application for teaching physics" Springer Open Journal, vol 3, p 449, 2014.

[10] A. Diseth, and O. Martinsen, “ Approach to learning, cognitive style, and motives as predictors of academic achievement". Educational Psychology UK, vol. 23, p. 195-207, 2013.

[11] L. F. Zhang. "Thinking styles: Their relationship with modes of thinking and academic performance". Educational Psychology UK, vo. 22 , p 331-348, 2002

[12] D. Chopra, and R. E. Tanzi, Super brain: Unleashing the explosive power of your mind to maximize health, happiness, and spiritual wellbeing. New York: Three Rivers Press, 2012.

[13] D. G. Amen, Change your brain change your body: Use your brain to get and keep the body you have always wanted. New York: Crown Publishing. 2010.

[14] R. Kurzweil, How to create a mind: The secret of human thought revealed. New York: Penguin Books. 2013.

[15] S. Peters, The chimp paradox: The mind management. London: Ebury Publishing. 2012.

[16] J. S. B. T. Evans, Dual processing accounts of reasoning, judgment, and social cognition. The Annual Review of Psychology. 2008.

[17] A. Maksum, and F. D. Khory, Model hubungan struktural pola berpikir, hasrat ingin tahu, dan performa akademik. Laporan penelitian. Surabaya: LPPM Unesa. 2019.

[18] W. Mischel, The marshmallow test: Mastering self-control. New York: Little, Brown \& Company. 2014.

[19] WHO (2018)? Time to deliver: Report of the WHO independent highlevel commission on noncommunicable diseases. Geneva: WHO Press.

[20] A. Noviani, Menkes: $65 \%$ penduduk sakit, klaim BPJS membengkak. Bisnis.com. 2015.

[21] E. A. Retaduari, Atasi defisit Rp 9 T, BPJS kesehatan ajukan skema cost sharing 8 penyakit. Detikfinance.com. 2017.

[22] B. Raharjo. BPJS diperkirakan rugi 28 triliun. Republika.co.id. 2019.

[23] A. Maksum, Olahraga bermutu untuk semua. Makalah disampaikan dalam Pekan Ilmiah Keolahragaan Pascasarjana Unesa Surabaya, 1720 September 2018 di Kampus Ketintang Surabaya, 2018. 